\title{
Sustainable Consumption Behaviour in The Context of Millennials in Indonesia - Can Environmental Concern, Self-efficacy, Guilt and Subjective Knowledge Make a Difference?
}

DOI: 10.7595/management.fon.2020.0001

\begin{abstract}
:
Research Question: This paper assesses the effect of environmental concern, self-efficacy, subjective knowledge and guilt on sustainable consumption behaviour. Motivation: This study focuses on predicting and explaining sustainable consumption behaviour by proposing a model comprised of environmental concern, self-efficacy, consumer guilt and subjective knowledge as predictors. Environmental concern is an important element in VBN theory proposed by Stern (1999). Meanwhile, self-efficacy is part of SCT theory by Bandura (1997); as for subjective knowledge, it is deemed to be a better predictor of environmental behaviour (Kollmuss \& Agyeman, 2002). Guilt is included in this model as it is an important emotion that can affect sustainable consumption behaviour, especially in the context of collectivist culture country like Indonesia (Lee et al., 2012). All these factors have been proven to be able to influence sustainable consumer behaviour. However, there are still a few studies that explore these factors altogether simultaneously, especially in the context of a developing country. Thus, this study tries to examine sustainable consumption behaviour by incorporating these factors altogether. Idea: The main idea of this study is to empirically assess the influence of proposed independent variables, namely environmental concern, self-efficacy, subjective knowledge and guilt on sustainable consumption behaviour. This study also tries to assess whether there is a significant difference of sustainable consumption behaviour among demographic groups such as gender, education and age. Data: The model is tested by conducting a survey using a self-administered questionnaire on 200 respondents. The respondents are younger millennials aged between 17-27. The questionnaire consists of questions about demographic profile and about the research instruments. Tools: This study uses descriptive research design and purposive sampling to collect the data. Research hypotheses were tested by multiple regression analysis. Findings: The result of this study shows that environmental concern, self-efficacy and environmental knowledge have an influence on sustainable consumption behaviour, where environmental knowledge contributes the most in predicting the aforementioned behaviour. Meanwhile, this study also finds that consumer guilt has no impact upon this behaviour. Contributions: This study gives additional insight and understanding of sustainable consumption behaviour in the context of millennials in a developing country. The findings of this study can be used by the government to formulate environmental policies as well as for businesses to formulate strategies to promote their environmentally-friendly products.
\end{abstract}

Keywords: Sustainable consumption behaviour, environmental concern, self-efficacy, consumer guilt, subjective knowledge JEL Classification: M83, M12

\section{Introduction}

Consumption is deemed to be one of the main contributors of environmental problems. Along with other production activities, consumption activities have been acknowledged as the main contributors of various environmental issues (Stern et al. in Tanner \& Kast, 2003). After all, consumption is the main reason of the 
products being produced, which makes it the source of man-made stress and natural environment problem (Heiskanen \& Pantzar, 1997). This also occurs in Indonesia, where many of its environmental problems are the direct and indirect consequences of irresponsible and excess consumption. One of the most concerning environmental problems in Indonesia is related to waste (Widjaja, 2014). Currently, Indonesia is on the $2^{\text {nd }}$ position on the ranking of countries with most plastic waste thrown to the sea (Adharsyah, 2019). Another agenda regarding excess consumption in Indonesia is related to energy consumption. In 2016, Indonesia's energy consumption was the highest in Southeast Asia (Tempo.co, 2016). This high consumption can be a problem as the source of energy resources is mostly unrenewable (Nordlund \& Garvill, 2003). It is even mentioned that Indonesia is predicted to suffer from energy deficit by 2021 if it does not find a way to utilize energy effectively and efficiently (Valenta, 2019).

Since consumption is considered as one of the major causes of these problems, the role of consumers as the main actors of consumption behaviour is needed. According to Berglund \& Matti (2006), the main responsibility for environmental degradation lies in the hands of consumers as main agents of consumption. Therefore, consumers' role is really significant in sustainable consumption behaviour approach. Here, sustainable consumption itself is perceived to be an effective solution since its goal is not only encouraging the consumption of environmentally-friendly products, but also reducing the consumption rate and changing consumers' lifestyle (Biswas \& Roy, 2015).

Many studies have tried to discover what factors can affect sustainable consumption behaviour and this also becomes the objective of this study. It is mentioned that individual-related factors play a significant role in explaining an individual's sustainable consumption behaviour (Kostadinova, 2016). These factors include environmental concern (Hedlund, 2011), self-efficacy (Straughan \& Roberts, 1999), consumer guilt and environmental knowledge (Mostafa, 2009). Heo and Muralidharan (2017) studied environmental knowledge, environmental concern and self-efficacy by using the belief-attitude-behaviour approach, in which belief is represented by self-efficacy and attitude is represented by environmental concern. These 2 variables then acted as mediators of environmental knowledge to sustainable consumption behaviour. For this study, these 3 variables will be investigated as independent variables, without mediator. This study will also add consumer guilt as one of the predictor as according to Antonetti and Maklan (2013), self-conscious emotions such as guilt can play an important role in influencing behaviour, whether directly or indirectly through self-efficacy. Thus, this study tries to examine sustainable consumption behaviour by incorporating these factors altogether.

Moreover, as most of the past studies were conducted in the developed countries, it is necessary to examine whether these aforementioned factors would also have effect on sustainable consumption behaviour in Indonesia, as the developing country. These factors may already be proven in the context of developed countries. However, the role of these factors in the developing countries, in which the condition and situation is completely different in comparison with the developed countries, is still undetermined (Handique, 2014). As for the subject, this study would investigate sustainable consumption behaviour of Millennials in Indonesia. Millennials are chosen since their proportion is the biggest in Indonesia, they comprise of $33.75 \%$ of Indonesia population or approximately 88 million people (Badan Pusat Statistik, 2018). Moreover, millennials are known to be a more environmentally-friendly generation (Sheahan, 2005 in Muralidharan et al., 2016).

\section{Literature Review}

\subsection{Sustainable consumption behaviour}

Sustainable consumption behaviour (SCB) is a type of consumption which tries to balance the social, economic and environmental needs of both current and future generations (Luchs et al., 2011). According to Biswas and Roy (2015), sustainable consumption behaviour can also be referred to as "the pattern of reduced consumption of natural resources, changing lifestyle and consumption of environmentally-friendly products in order to meet the present needs and aspirations of the future generations" (p.464). Wang et al. (2014) grouped SCB into 5 categories: improving quality of life, meeting the needs sustainably, improving resource efficiency, reducing the waste and promoting the use of renewable sources.

There are a lot of factors identified as predictors of SCB. These factors can be categorized into individualrelated factors and context-related/situational factor (Kostadinova, 2016). Individual-related factors consist of attitudes, values, beliefs, demographic characteristics and other variables that can influence individuals' behaviour (Kostadinova, 2016). Meanwhile, contextual-related or situational factors are external forces, such as product value, brand popularity, environment, regulation and other factors that can affect individuals' behaviour (Kostadinova, 2016). This study will try to explain the SCB of younger millennials of Indonesia from the individual-related factors perspective. 


\subsection{Environmental concern}

One of the models used to explain sustainable consumption behaviour is the value-belief-norm (VBN) theory developed by Stern in 1991 (Phipps et al., 2013). According to VBN theory, if an individual possesses strong altruistic and biospheric values, he/she tends to easily accept the beliefs of the NEP worldview (Phipps et al., 2003). The NEP scales are often used to measure the degree of individuals' environmental concern (Fransson \& Garling, 1999). Environmental concern itself is defined as a general attitude, which centers on the cognitive and affective evaluation of the environmental protection of the object (Bamberg, 2003).

Environmental concern has a huge impact in motivating individuals to make an environmentally-friendly decision (SGuin et al., 1998). This impact is proven by many studies examining the relationship between environmental concern and environmentally related behaviour, such as purchasing environmentally-friendly product (Kim \& Choi, 2005) and willingness to pay more for an environmentally-friendly product (Bang et al., 2000) which indicates that a strong environmental concern increases the likelihood of pro-environmental behaviour (Hedlund, 2011). Based on these notions, the following hypothesis is proposed:

Hypothesis 1 - Environmental concern has a positive effect towards sustainable consumption behaviour

\subsection{Self-efficacy}

Another theory explaining sustainable consumption behaviour is the social cognitive theory (SCT). Under SCT, an individual is an agent who is capable in controlling his/her own functioning and environmental events (Bandura, 1997). In this sense, an individual's interpretation of his/her own behaviour would influence self-efficacy or competence, which in turn impact incoming behaviour (Bandura, 1997). Self-efficacy itself is a measure of an individual's evaluation of his/her ability in influencing environmental problems (Kang et al., 2013).

Self-efficacy is an important element of consumers' decision regarding their sustainable consumption behaviour. According to Roberts (1996), before conducting a certain behaviour, consumers have to possess beliefs that their actions would make an impact. These beliefs result from consumers' own values which provide the ground for their action. Self-efficacy has been consistently linked to sustainable or social consumption behaviour. Cleveland et al. (2005) also state that environmental concern alone is not enough. Consumers need to feel empowered in order to be able to convert this concern into actual behaviour; therefore self-efficacy is needed along with environmental concern (Cleveland et al., 2005). Based on these arguments, the following hypothesis is proposed:

Hypothesis 2 - Self-efficacy has a positive effect towards sustainable consumption behaviour

\subsection{Subjective knowledge}

Fryxell \& Lo (2003, p.45) defined environmental knowledge as "a general knowledge of facts, concepts, and relationships concerning the natural environment and its major ecosystems". Tanner \& Kast (2003) differentiated environmental knowledge into two categories: factual knowledge (objective knowledge) and action-related knowledge (subjective knowledge). It is suggested that action-related knowledge or subjective knowledge plays a bigger role in predicting environmental behaviour compared to the other type of knowledge. Therefore, this study will focus on this type of knowledge to explain sustainable consumption behaviour.

According to Kollmuss \& Agyeman (2002), subjective knowledge is one of internal factors that can influence sustainable consumption behaviour. Subjective knowledge is considered to be a distinguishing factor between an individual who is more actively involved in environmental action compared to an individual who is less actively involved (Stern, 1992). The individual will be more inspired to behave responsibly towards environment if he/she is more aware of environmental issues and their sources (Kollmuss \& Agyeman, 2002). Based on these notions, this study proposes the following hypothesis:

Hypothesis 3 - Subjective knowledge has a positive effect towards sustainable consumption behaviour

\subsection{Consumer guilt}

According to Tracy \& Robins (2004), self-conscious emotions are activated when people compare their behaviour to their own personal or social norm. On the subject of sustainable consumption behaviour, recent studies increasingly focus on two particular emotions - pride and guilt (Schneider et al., 2017; Onwezen et al., 2014). These two emotions are considered to be relevant in sustainable consumption behaviour as they can affect individuals' social concern and moral consideration (Schneider et al., 2017). 
Though both emotions are relevant in influencing sustainable consumption behaviour, the effect is different across the culture (Onwezen et al., 2014). According to Lee et al. (2012), the effect of guilt on sustainable consumption behaviour is stronger in a collectivistic culture rather than in an individualistic culture. As Indonesia is partly a collectivistic country, this study will only employ guilt as one of suggested sustainable consumption behaviour predictors.

According to Watson \& Spence (2007), guilt is a subjective feeling resulting from an individual's realization of having violated his/her own personal or social moral standards. Guilt occurs when individuals feel that they fail to meet their moral standard. Preserving the environment has been considered a right thing to do, hence sustainable consumption behaviour can be considered to be a moral standard. When an individual fails to act sustainably, the anticipated guilt is likely to occur (Basil et al., 2006). Several studies have proven that guilt plays an important role in predicting pro-environmental behaviour (Tracy \& Robbins, 2006; Brennan \& Binney, 2010). Based on these notions, the following hypothesis is proposed:

Hypothesis 4: Guilt has a positive effect on sustainable consumption behaviour

\subsection{Research framework}

Based on research hypotheses proposed earlier, a research model is constructed. This model tries to predict sustainable consumption behaviour by employing 4 individual-related factors as predictors as can be seen in Figure 1 below

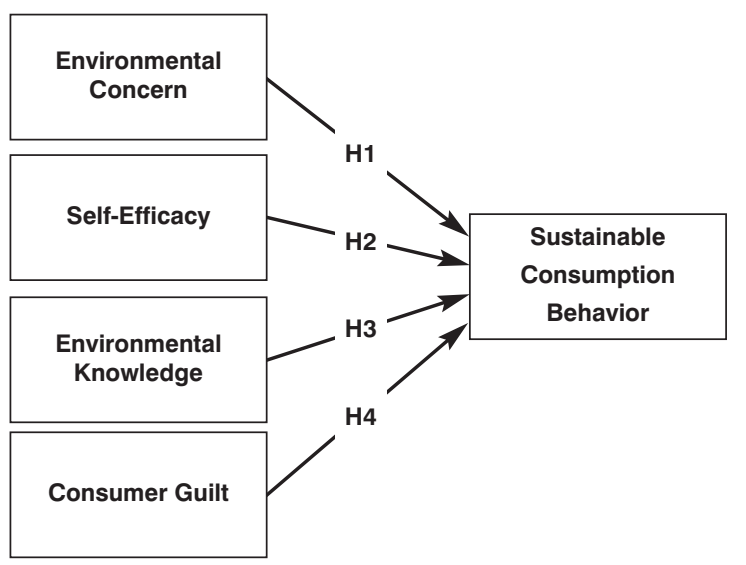

Figure 1: Research Framework

\section{Methodology}

\subsection{Sample and methodology}

The subject of this study is a younger millennial, aged between 18 and 27. Younger millennials are chosen due to their influence upon the family's decision making, both directly and indirectly (Fry, 2015). In relation to environmental issues, millennials are known as environmentally-conscious consumers (Sheahan, 2005 in Muralidharan et al., 2016). It is mentioned that $33.75 \%$ of Indonesian population are millennials, with an estimated total number 88 million people (Badan Pusat Statistik, 2018). Since there is no available sampling frame for millennials in Indonesia, this study uses non a probability sampling method, specifically the convenience sampling method to acquire the sample. The total number in the sample in this study is 200 respondents. In this study, both descriptive and inferential statistical analyses are administered. As for statistical analysis, it is concerned with assessing the measurement scales and testing the research hypotheses. Validity and reliability analyses are used to assess the measurement scales. For the purpose of testing the research hypotheses, multiple regression analysis is employed. 


\subsection{Measurement}

All latent variables in this study were measured using multiple statements on five-point Likert scale ranging from (1) "very disagree" to (5) "very agree". In this study, the scale to measure environmental concern was modified from NEP scale developed by Dunlap et al. (2000). Self-efficacy was measured by a scale adopted from Heo \& Muralidharan (2017). The scale for environmental knowledge was adapted from Mostafa (2009). Then, to measure consumer guilt, this study adapted the scale developed by Theotokis \& Manganari (2015). For sustainable consumption behaviour, this study used the measurement from Wang et al. (2014).

\section{Results and Discussions}

\subsection{Characteristics of sample}

As can be seen from Table 1, the sample comprises $59 \%$ female and $41 \%$ male respondents. In the demographic section, we also collect information about respondents' age, occupation and education. A majority of the respondents are students, followed by office workers and entrepreneurs, with the percentage of $37 \%$ and $13 \%$ respectively. Regarding the age, the majority of respondents are in the $24-25$ age group, scoring $38.5 \%$. As for the education, most of the respondents are undergraduates, and they make up $69.5 \%$ of the sample.

Table 1: Descriptive data

\begin{tabular}{|l|c|c|}
\hline & Percentage & SCB Score \\
\hline Gender & & \\
\hline Male & $41 \%$ & 3.14 \\
\hline Female & $59 \%$ & 3.46 \\
\hline \hline Age & & \\
\hline $18-19$ & $9 \%$ & 3.28 \\
\hline $20-21$ & $21 \%$ & 3.28 \\
\hline $22-23$ & $24.5 \%$ & 3.42 \\
\hline $24-25$ & $38.5 \%$ & 3.34 \\
\hline $26-27$ & $7 \%$ & 3.12 \\
\hline \hline Education & & \\
\hline High School & $10 \%$ & 2.97 \\
\hline Undergraduate & $69.5 \%$ & 3.32 \\
\hline Postgraduate & $16.5 \%$ & 3.57 \\
\hline Other & $4 \%$ & 3.22 \\
\hline \hline Expenditure & & \\
\hline$<$ Rp. 1.000.000 & $9 \%$ & 3.03 \\
\hline Rp 1.000.001 - Rp. 2000.000 & $31.5 \%$ & 3.40 \\
\hline Rp 2.000.001 - Rp. 3000.000 & $27.5 \%$ & 3.34 \\
\hline Rp 3.000.001 - Rp. 4000.000 & $16 \%$ & 3.24 \\
\hline Rp 4.000.001 - Rp. 5000.000 & $7.5 \%$ & 3.37 \\
\hline$>$ Rp. 5.000.000 & & 3.45 \\
\hline
\end{tabular}

\subsection{Validity and reliability of measurement}

This study conducted validity and reliability analyses to evaluate the applicability of multi-item scales used to measure each variable employed in this study (Knapp \& Mueller, 2010).

The study employed the factor analysis for assessing validity of the measurements. The measurements are deemed valid if factor loading is $\geq 0.5$ (Stevens, 2009). As can be seen from Table 2, all measurements used in this study are deemed to be valid as they already fulfill the minimum criteria used in this study.

Meanwhile, the reliability analysis of this study is based on alpha or Cronbach's alpha where the value of 0.6 or above is considered favourable (Malhotra, 2010). As presented in Table 2, all measurements are considered reliable as all of them exceed the minimum criteria used in this study. 
Table 2: Validity and reliability

\begin{tabular}{|c|c|c|c|c|c|}
\hline Variable & Item & Code & $\begin{array}{c}\text { Factor } \\
\text { Loading }\end{array}$ & KMO & $\begin{array}{l}\text { Cronbach's } \\
\text { Alpha }\end{array}$ \\
\hline \multirow{4}{*}{$\begin{array}{l}\text { Environmental Concern } \\
\text { (Dunlap et al, 2000) }\end{array}$} & $\begin{array}{l}\text { Despite our special abilities, humans are still subject to } \\
\text { the laws of nature }\end{array}$ & EC1 & 0.905 & \multirow{4}{*}{0.853} & \multirow{4}{*}{0.911} \\
\hline & $\begin{array}{l}\text { If things continue on their present course, we will soon } \\
\text { experience a major ecological catastrophe }\end{array}$ & $\mathrm{EC} 2$ & 0.881 & & \\
\hline & $\begin{array}{l}\text { When humans interfere with nature it often produces } \\
\text { disastrous consequence }\end{array}$ & $\mathrm{EC} 3$ & 0.880 & & \\
\hline & Humans are severely abusing the environment & $\mathrm{EC} 4$ & 0.890 & & \\
\hline \multirow{3}{*}{$\begin{array}{l}\text { Self-Efficacy } \\
\text { (Heo \& Muralidharan, 2017) }\end{array}$} & $\begin{array}{l}\text { It is worthless for the individual consumer to do anything } \\
\text { about pollution }(R)\end{array}$ & SE1 & 0.864 & \multirow{3}{*}{0.722} & \multirow{3}{*}{0.822} \\
\hline & $\begin{array}{l}\text { Since one person cannot have any effect upon pollution } \\
\text { and natural resource problems, it doesn't make any } \\
\text { difference what I do }(R)\end{array}$ & SE2 & 0.863 & & \\
\hline & $\begin{array}{l}\text { Each consumer's behavior can have a positive effect on } \\
\text { society by purchasing products sold by socially } \\
\text { responsible companies }\end{array}$ & SE3 & 0.855 & & \\
\hline \multirow{5}{*}{$\begin{array}{l}\text { Environmental Knowledge } \\
\text { (Mostafa, 2009) }\end{array}$} & $\begin{array}{l}\text { I know that I buy products and packages that are } \\
\text { environmentally safe. }\end{array}$ & EK1 & 0.728 & \multirow{5}{*}{0.848} & \multirow{5}{*}{0.884} \\
\hline & I know more about recycling than the average person. & $\mathrm{EK} 2$ & 0.826 & & \\
\hline & $\begin{array}{l}\text { I know how to select products and packages that reduce } \\
\text { the amount of waste ending up in landfills. }\end{array}$ & EK3 & 0.843 & & \\
\hline & $\begin{array}{l}\text { I understand the environmental phrases and symbols on } \\
\text { product package. }\end{array}$ & EK4 & 0.881 & & \\
\hline & I am knowledgeable about environmental issues & EK5 & 0.847 & & \\
\hline \multirow{3}{*}{$\begin{array}{l}\text { Consumer Guilt } \\
\text { (Theotokis \& Manganari, } \\
\text { 2015) }\end{array}$} & $\begin{array}{l}\text { I feel irresponsible if I'm not helping in protecting the } \\
\text { environment }\end{array}$ & CG1 & 0.905 & \multirow{3}{*}{0.749} & \multirow{3}{*}{0.898} \\
\hline & $\begin{array}{l}\text { I feel guilty if I don't participate in environmental } \\
\text { program }\end{array}$ & CG2 & 0.926 & & \\
\hline & $\begin{array}{l}\text { I feel accountable about not helping to protect the } \\
\text { environment }\end{array}$ & CG3 & 0.908 & & \\
\hline \multirow{5}{*}{$\begin{array}{l}\text { Sustainable Consumption } \\
\text { Behavior } \\
\text { (Wang et al, 2014) }\end{array}$} & I use renewable energy & SCB1 & 0.821 & \multirow{5}{*}{0.858} & \multirow{5}{*}{0.856} \\
\hline & I try to save water usage & SCB2 & 0.809 & & \\
\hline & I recycle plastic waste & SCB3 & 0.795 & & \\
\hline & $\begin{array}{l}\text { I repair damaged products and use them until they cannot } \\
\text { be repaired }\end{array}$ & SCB4 & 0.810 & & \\
\hline & $\begin{array}{l}\text { I purchase products with environmental label or green } \\
\text { labelling }\end{array}$ & SCB5 & 0.764 & & \\
\hline
\end{tabular}

\subsection{Hypotheses testing and result}

Regression analysis was conducted to test the research hypotheses as well as to examine the relationships between the dependent variable and its predictor. In the context of this study, the purpose of the regression analysis is to investigate the influence of environmental concern, self-efficacy, environmental knowledge and consumer guilt towards sustainable consumption behaviour. Based on the result presented in table 3 , it can be concluded that the model is significant with F-value of 33.527 and adjusted $R^{2}$ of 0.395 . This indicates that $39.5 \%$ variance of sustainable consumption behaviour can be accounted for by its predictor, which are environmental concern, self-efficacy and environmental knowledge. On the other hand, the remaining $60.5 \%$ of the sustainable consumption behaviour is explained by external factors which are not captured by this study. As mentioned before, sustainable consumption behaviour can be explained from the contextual factor perspective and the individual-related factor perspective (Kostadinova, 2016). Here, the unexplained variance might be attributed to the contextual factors like product attributes, regulation or other individual related factors that were not included in this study, such as values, norms and demographic characteristics. At a 95 percent confidence interval, environmental concern $(B=0.118, p<0.05)$, self-efficacy $(B=0.139$, $p<0.05)$ and environmental knowledge $(B=0.465, p<0.05)$ are proven to have significant effects on sustainable consumption behaviour. On the other hand, consumer guilt ( $B=0.061, p>0.05$ ) has no significant effect on sustainable consumption behaviour. 
Table 3: Summary of regression analysis

\begin{tabular}{lcccccc}
\hline & Beta & t-values & Significance & $\mathrm{R}^{2}$ & Ad R $^{2}$ & F Value \\
\hline Environmental Concern & 0.118 & 2.660 & $0.008^{\star}$ & 0.407 & 0.395 & 33.527 \\
Self-efficacy & 0.139 & 2.447 & $0.015^{\star}$ & & & \\
Subjective Knowledge & 0.465 & 8.700 & $0.000^{\star}$ & & & \\
Consumer Guilt & 0.061 & 1.303 & 0.194 & & & \\
Intercept & 0.651 & 2.335 & $0.021^{\star}$ & & & \\
\hline
\end{tabular}

Note: ${ }^{*} p<0.05$

\subsection{Discussion}

This study has found environmental knowledge to be the biggest predictor of sustainable consumption behaviour in this model. An individual who feels that he/she understands a lot about environmental issue will have a bigger tendency to perform a sustainable consumption behaviour act (Mostafa, 2009). Thus, it is suggested that the environmental knowledge be incorporated into the education program as early as possible due to the reason that the attitude of individuals is developed during childhood and adolescence (McGuire, 2015)

It is also important to determine the type of environmental knowledge to be applied. Knowing about environmental issues alone is not enough; an individual also has to possess understanding and confidence towards the issue. Understanding and being confident that he/she understands about the environmental issue will create personal connection and involvement between an individual and the environmental issue (Mostafa, 2009). Based on this result, it is suggested that subjective knowledge should be incorporated in environmental education, along with the traditional approach, which is objective knowledge. Rather than only learning about environmental problems in class, it is better to also bring the students directly to the field, for example visiting the recycling site, visiting a polluted river etc. If the students are learning about environmental issues right at the site, it would be more likely for them to engage in sustainable consumption behaviour. Ahmad and Nordin (2004) also suggested that experiential learning is better to be applied as it is more effective in transferring knowledge and altering behaviours. As also asserted by Kollmus and Agyeman (2002), the use of a non-traditional way of learning, such as experiential learning, may be more effective in encouraging the change in behaviour.

With regard to environmental concern, the result indicates that the higher concern an individual attaches to environmental condition, the higher the likelihood for him/her to conduct a sustainable consumption behaviour. This result is in line with the study by Follows \& Jobber (2000), asserting that when consumers are highly concerned about environmental condition, they will be more likely to evaluate their decisions. Based on this result, it is suggested for the marketer to incorporate environmental concern into the marketing campaign for the environmentally-friendly product. The campaign should not only intend to promote the green product, but also highlight consumers about the seriousness of environmental issues we are facing right now.

Nevertheless, according to Cleveland et al. (2005), environmetal concern alone is not enough. Consumers also need to feel empowered in order to be able to convert this concern into actual behaviour, therefore selfefficacy is needed (Cleveland et al., 2005). This study has found that self-efficacy significantly influences sustainable behaviour. And similarly to findings reported by Roberts (1996), Straughan \& Roberts (1999) and Tan (2011), this study has found that self-efficacy is a better predictor for sustainable consumption behaviour than environmental concern. Based on this result, in promoting green product the marketer should not only explain the feature of the product, but also highlight the role of the green product in combating environmental problems. The campaign has to be tailored so that it can showcase both the seriousness of the environmental problem (to affect consumers' environmental concern) and the contribution the consumers will make if they buy the product (self-efficacy). The same message can also be applied to the campaign to encourage other pro-environmental behaviours such as reducing the usage of energy, recycling, and separating the waste.

As for consumer guilt, this study has found that consumer guilt has no significant effect on the sustainable concern. It is similar with the study from Bissing-Olson et al. (2016). The possible reason for this insignificant result is perhaps in that individuals find alternative ways to alter their guilt and release themselves from the need to act sustainably. Moreover, according to Bissing-Olson et al. (2016), the feelings of guilt cannot be translated to sustainable consumption behaviour due to the contextual constraints such as low physical access (lack of public transportation, limited availability of environmentally-friendly product) and high cost of conducting such behaviour (high price of environmentally-friendly product, high switching cost of envi- 
ronmentally-friendly product). These constraints can make individuals develop arguments and reasoning as to why they cannot engage in sustainable consumption behaviour (Bissing-Olson et al., 2016).

\subsection{Limitations and suggestions}

This study still has several limitations, hence several suggestions for future studies are thereby proposed. First, as this study employed the non-probability sampling, the result may only be applied to the sample of the study and cannot be generalized to the whole population. Next, it is suggested that the objective knowledge variable should also be included in order to get a clear comparison between objective knowledge and subjective knowledge. Additionally, future research can also focus on a specific type of sustainable consumption behaviour, for example focusing only on the buying behaviour or the curtailment behaviour. Regarding methodology, incorporating triangulation is encouraged in order to gain more insight into what factors may be relevant in influencing sustainable behaviour. Next, the study sample is limited to Jabodetabek area only. We suggest that the research should be conducted in other areas of Indonesia as well. Future research is also encouraged to conduct a longitudinal study to capture the actual behaviour as well as the continuity of the behaviour.

\section{Conclusion}

This study gives an insight regarding the role of individual-related factors in influencing sustainable consumption behaviour in the context of millennials in a developing country The findings of this study highlight the importance of incorporating subjective knowledge in environmental education, the importance of making the millennials aware and have concern for the environmental problems, as well as the importance of making the millennials feel needed as regards tackling environmental problems. This study shows that rather than make the millennials feeling guilty about the consequences of their unsustainable act, it is better to boost their morale by showing how important their roles in environmental perseverance are. The government and the company have to able to convince the millennials that every action they take, no matter how little they may be, will make a difference in the environment perseverance.

\section{REFERENCES}

[1] Adharsyah, T. (2019), Sebegini Parah ternyata Masalah Sampah Plastik di Indonesia. CNBC Indonesia. Retrieved from <accessed on 05 October 2019>

[2] Ahmad, T. B. T., \& Nordin, M. S. (2014). University Students' Subjective Knowledge of Green Computing and Pro-Environmental Behaviour. International Education Studies, 7(2), 64-74. DOI:10.5539/ies.v7n2p64

[3] Bang, H. K., Ellinger, A. E., Hadjimarcou, J., \& Traic hal, P. A. (2000). Consumer concern, knowledge, belief, and attitude toward renewable energy: An application of the reasoned action theory. Psychology \& Marketing, 17(6), 449-468. DOI: 10.1002/(SICI)1520-6793(200006)17:6<449::AID-MAR2>3.0.CO;2-8

[4] Antonetti, P., \& Maklan, S. (2014). Feelings that make a difference: How guilt and pride convince consumers of the effectiveness of sustainable consumption choices. Journal of Business Ethics, 124(1), 117-134. DOI: $10.1007 / \mathrm{s} 10551-013-1841-9$

[5] Badan Pusat Statistik. (2018), Profil Generasi Milenal Indonesia 2018. Retrieved from . <accessed on 5 October 2019>

[6] Bamberg, S. (2003). How does environmental concern influence specific environmentally related behaviours? A new answer to an old question. Journal of Environmental Psychology, 23, 21-32. DOI:10.1016/s0272-4944(02)00078-6

[7] Bandura, A. (1997), Self-efficacy: The Exercise of Control, New York, W.H. Freeman \& Co.

[8] Basil, D. Z., Ridgway, N. M., \& Basil, M. D. (2006). Guilt appeals: The mediating effect of responsibility. Psychology \& Marketing, 23(12), 1035-1054. DOI:10.1002/mar.20145

[9] Berglund, C., \& Matti, S. (2006). Citizen and consumer: The dual role of individuals in environmental policy. Environmental Politics, 15 (4). DOI: 10.1080/09644010600785176

[10] Bissing-Olson, M. J., Fielding, K. S., \& lyer, A. (2016). Experiences of pride, not guilt, predict pro-environmental behaviour when pro-environmental descriptive norms are more positive. Journal of Environmental Psychology, 45, 145-153. DOI: 10.1016/j.jenvp.2016.01.001

[11] Biswas, A., \& Roy, M. (2015). Green products: An exploratory study on the consumer behaviour in emerging economies of the east. Journal of Cleaner Production, 87, 463-468. DOI: 10.1016/j.jclepro.2014.09.075 
[12] Brennan, L., \& Binney, W. (2010). Fear, guilt, and shame appeals in social marketing. Journal of business Research, 63(2), 140-146. DOI: 10.1016/j.jbusres.2009.02.006

[13] Cleveland, M., Kalamas, M., \& Laroche, M. (2005). Shades of green: Linking environmental locus of control and pro-environmental behaviours. Journal of Consumer Marketing, 22(4), 198-212. DOI: $10.1108 / 07363760510605317$

[14] Dunlap, R. E., Van Liere, K. D., Mertig, A. G., \& Jones, R. E. (2000). New trends in measuring environmental attitudes: measuring endorsement of the new ecological paradigm: a revised NEP scale. Journal of social issues, 56(3), 425-442. DOI: 10.1111/0022-4537.00176

[15] Follows, S. B., \& Jobber, D. (2000). Environmentally responsible purchase behaviour: a test of a consumer model. European journal of Marketing, 34(5/6), 723-746. DOI: 10.1108/03090560010322009

[16] Fransson, N., \& Gärling, T. (1999). Environmental concern: Conceptual definitions, measurement methods, and research findings. Journal of environmental psychology, 19(4), 369-382. DOI: 10.1006/jevp.1999.0141

[17] Fry, R. (2015). More millennials living with family despite improved job market. Washington, DC: Pew Research Center. Retrieved from http://www.pewsocialtrends.org/2015/07/29/more-millennials-livingwith-family-despite-improved-job-market/

[18] Fryxell, G. E., \& Lo, C. W. H. (2003). The influence of environmental knowledge and values on managerial behaviours on behalf of the environment: An empirical examination of managers in china. Journal of Business Ethics, 46(1), 45-69. DOI: 10.1037/e711752011-001

[19] Handique, K. (2014). Role of Collectivism, Environmental Concern, Scepticism and Perceived Consumer Effectiveness on Green Purchasing Behaviour of Consumers of Guwahati, India. The International Journal of Business \& Management, 2(10), 58.

[20] Hedlund, T. (2011). The impact of values, environmental concern, and willingness to accept economic sacrifices to protect the environment on tourists' intentions to buy ecologically sustainable tourism alternatives. Tourism and Hospitality Research, 10, 278-288. DOI: 10.1177/1467358411423330

[21] Heiskanen, E., \& Pantzar, M. (1997). Toward sustainable consumption: Two new Perspectives. Journal of Consumer Policy, 20, 409-442. DOI: 10.1023/a:1006862631698

[22] Heo, J., \& Muralidharan, S. (2017). What triggers young Millennials to purchase eco-friendly products?: the interrelationships among knowledge, perceived consumer effectiveness, and environmental concern. Journal of Marketing Communications, 1-17. DOI: 10.1080/13527266.2017.1303623

[23] Kang, J., Liu, C., \& Kim, S. H. (2013). Environmentally sustainable textile and apparel consumption: the role of consumer knowledge, perceived consumer effectiveness and perceived personal relevance. International Journal of Consumer Studies, 37(4), 442-452. DOI: 10.1111/ijcs.12013

[24] Kim, Y., \& Choi, S. M. (2005). Antecedents of green purchase behaviour: An examination of collectivism, environmental concern, and PCE. ACR North American Advances. DOI: 10.1002/mar.20698

[25] Knapp, T, \& Mueller, R. (2010). Reliability and Validity of Instruments. In: The Reviewer's Guide to Quantitative Methods in the Social Sciences, G. Hancock, \& R. Mueller, New York, Routledge, 337-355. DOI: 10.4324/9780203861554

[26] Kollmuss, A., \& Agyeman, J. (2002). Mind the gap: why do people act environmentally and what are the barriers to pro-environmental behaviour. Environmental education research, 8(3), 239-260. DOI: $10.1080 / 13504620220145401$

[27] Kostadinova, E. (2016). Sustainable consumer behaviour: Literature overview. Economic Alternatives, 2 , 224-234.

[28] Lee, Y. K., Choi, J. G., Kim, M. S., Ahn, Y. G., \& Katz-Gerro, T. (2012). Explaining pro-environmental behaviours with environmentally relevant variables: A survey in Korea. African Journal of Business Management, 6(29), 8677-8690.

[29] Luchs, M. G., Naylor, R. W., Irwin, J. R., \& Raghunathan, R. (2010). The sustainability liability: Potential negative effects of ethicality on product preference. Journal of Marketing, 74(5), 18-31. DOI: 10.1509/jmkg.74.5.18

[30] Malhotra, N.K. (2010). Marketing Research: An Applied Orientation, 6th Edition, New Jersey, Prentice Hall.

[31] McGuire, N. M. (2015). Environmental Education and Behavioural Change: An Identity-Based Environmental Education Model. International Journal of Environmental and Science Education, 10(5), 695-715. DOI: 10.12973/ijese.2015.261a

[32] Mostafa, M. M. (2009). Shades of green: A psychographic segmentation of the green consumer in Kuwait using self-organizing maps. Expert Systems with Applications, 36(8), 11030-11038. DOI: 10.1016/j.eswa.2009.02.088

[33] Muralidharan, S., Rejón-Guardia, F., \& Xue, F. (2016). Understanding the green buying behaviour of younger Millennials from India and the United States: A structural equation modeling approach. Journal of International Consumer Marketing, 28(1), 54-72. DOI:10.1080/08961530.2015.1056328 
[34] Nordlund, A. M., \& Garvill, J. (2003). Effects of values, problem awareness, and personal norm on willingness to reduce personal car use. Journal of environmental psychology, 23(4), 339-347. DOI: 10.1016/S0272-4944(03)00037-9

[35] Onwezen, M. C., Bartels, J., \& Antonides, G. (2014). Environmentally friendly consumer choices: Cultural differences in the self-regulatory function of anticipated pride and guilt. Journal of Environmental Psychology, 40, 239-248. DOI: 10.1016/j.jenvp.2014.07.003

[36] Phipps, M., Ozanne, L. K., Luchs, M. G., Subrahmanyan, S., Kapitan, S., Catlin, J. R., ... \& Weaver, T. (2013). Understanding the inherent complexity of sustainable consumption: A social cognitive framework. Journal of Business Research, 66(8), 1227-1234. DOI: 10.1016/j.jbusres.2012.08.016

[37] Roberts, J. A. (1996). Green consumers in the 1990s: profile and implications for advertising. Journal of business research, 36(3), 217-231. DOI:10.1016/0148-2963(95)00150-6

[38] Schneider, C. R., Zaval, L., Weber, E. U., \& Markowitz, E. M. (2017). The influence of anticipated pride and guilt on pro-environmental decision making. PloS one, 12(11), e0188781. DOI: 10.1371/journal.pone.0188781

[39] SGuin, C., Pelletier, L. G., \& Hunsley, J. (1998). Toward a model of environmental activism. Environment and Behaviour, 30(5), 628-652. DOI: 10.1177/001391659803000503

[40] Stern, P. C., Dietz, T., Abel, T., Guagnano, G. A., \& Kalof, L. (1999). A value-belief-norm theory of support for social movements: The case of environmentalism. Human ecology review, 81-97.

[41] Stevens, J. (2009), Applied Multivariate Statistics for the Social Sciences, 5th Edition, New York, Routledge. DOI:10.4324/9780203843130

[42] Straughan, R. D., \& Roberts, J. A. (1999). Environmental segmentation alternatives: a look at green consumer behaviour in the new millennium. Journal of consumer marketing, 16(6), 558-575. DOI: $10.1108 / 07363769910297506$

[43] Tan, B. C. (2011). The role of perceived consumer effectiveness on value-attitude-behaviour model in green buying behaviour context. Australian journal of basic and applied sciences, 5(12), 1766-1771.

[44] Tanner, C., \& Wölfing Kast, S. (2003). Promoting sustainable consumption: Determinants of green purchases by Swiss consumers. Psychology \& Marketing, 20(10), 883-902. DOI:10.1002/mar.10101

[45] Tempo.co. (2016), Kebutuhan Energi di Indonesia Tertinggi di ASEAN. Tempo.co. Retrieved from <Accesed on 7 October 2019>

[46] Theotokis, A., \& Manganari, E. (2015). The impact of choice architecture on sustainable consumer behaviour: The role of guilt. Journal of Business Ethics, 131(2), 423-437. DOI: 10.1177/0272989X13507339.

[47] Tracy, J. L., \& Robins, R. W. (2004). Putting the Self into Self-Conscious Emotions: A Theoretical Model. Psychological Inquiry, 15(2), 103-125. DOI: 10.1207/s15327965pli1502_01

[48] Tracy, J. L., \& Robins, R. W. (2006). Appraisal antecedents of shame and guilt: Support for a theoretical model. Personality and social psychology bulletin, 32(10), 1339-1351.

[49] Valenta, E. (2019), Indonesia Diprediksi Defisit Energi pada 2012. Beritagar.id. Retrieved from <Accessed on 07 October 2019>

[50] Widjaja, E. (2014), Sweeping Opportunities in Indonesia's Waste Management Industry: A Global Business Guide. Retrieved from < accessed on 2 October 2019>

[51] Wang, P., Liu, Q., \& Qi, Y. (2014). Factors influencing sustainable consumption behaviours: a survey of the rural residents in China. Journal of Cleaner Production, 63, 152-165. DOI: 10.1016/j.jclepro.2013.05.007

[52] Watson, L., \& Spence, M. T. (2007). Causes and consequences of emotions on consumer behaviour: A review and integrative cognitive appraisal theory. European Journal of Marketing, 41(5/6), 487-511. DOI: 10.1108/03090560710737570.

Received: 2019-05-01 Revisions requested: 2019-09-30 Revised: 2020-01-08 (3 revisions)

Accepted: 2020-01-15 


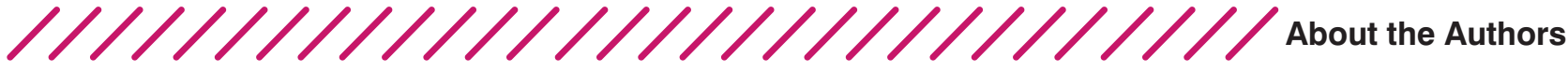

\author{
Nosica Rizkalla \\ Universitas Multimedia Nusantara, Faculty of Business, Indonesia \\ e-mail: nosica.rizkalla@umn.ac.id
}

Nosica Rizkalla, S.E., MSc works as a lecturer at Universitas Multimedia Nusantara. She teaches marketing-related subjects such as marketing management, business communication and marketing research. She earned her Bachelor's degree from

Universitas Indonesia and Master's degree from University of Nottingham, United Kingdom. Her current research is focusing on sustainable consumption behaviour and ethical consumption.

Trihadi Pudiawan Erhan

Universitas Multimedia Nusantara, Faculty of Business, Indonesia e-mail: trihadi.pudiawan@umn.ac.id

Trihadi Pudiawan, S.E., M.S. Trihadi Pudiawan Erhan is currently a lecturer at the Faculty of Business, Universitas Multimedia Nusantara. He earned his master's degree in economic science from Universitas Indonesia and a bachelor's degree in marketing from Prasetiya Mulya Business School. Aside from lecturing, he is also actively engaged in doing research that is funded internally by the university as well as by the government of Indonesia. He is also a certificate facilitator from MarkPlus Institute that are

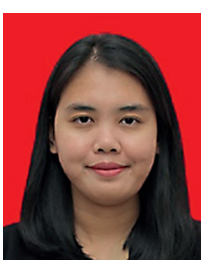
specializing in the field of branding and marketing. 